\title{
Amphibian embryos as an alternative model to study the pharmaceutical toxicity of cyclophosphamide and ibuprofen
}

\author{
Blerta Turani, ${ }^{1}$ Valbona Aliko, ${ }^{2}$ Caterina Faggio ${ }^{3}$ \\ ${ }^{1}$ Department of Food Technology, High Professional College, "Qiriazi” University College, Tirana, Albania; \\ ${ }^{2}$ Department of Biology, Faculty of Natural Sciences, University of Tirana, Tirana, Albania; ${ }^{3}$ Department of Chemical, \\ Biological, Pharmaceutical and Environmental Sciences, University of Messina, Messina, Italy
}

\begin{abstract}
Pharmaceuticals are becoming potentially ubiquitous pollutants because of their extensive use by man. One of the most frequent groups of pharmaceuticals that have been identified as particularly concerning is that of nonsteroidal anti-inflammatory and chemotherapeutic drugs. In Albania, studies to determine the risk of pharmaceuticals in conjunction with their occurrence in water bodies and their adverse effects on living organisms, including humans, are scarce. The purpose of this study was to elucidate the possible toxic effects of ibuprofen (IBU) and cyclophosphamide (CP) on cellular physiology of frog tadpoles. For this purpose, individuals of Pelophylax shqipericus belonging to stage 21 Gosner were exposed to sub-lethal concentration $(5 \mu \mathrm{g} / \mathrm{L})$ of IBU and CP for 48 hours, and erythrocyte abnormalities and micronucleated cell frequency were evaluated as endpoints. Blood smears from tadpoles exposed to CP for 48 hours showed a pronounced
\end{abstract}

Correspondence: Blerta Turani, Department of Food Technology, High Professional College, "Qiriazi” University College, Taulantët Street, Kodër-Kamëz, Tirana 1029, Tirana, Albania.

E-mail: blertaturani@yahoo.com

Key words: Amphibian embryos; Tadpoles; Pharmaceuticals; Ibuprofen; Cyclophosphamide.

Conflict of interest: the authors declare no potential conflict of interest.

Funding: the work was supported by the University of Tirana, Albania.

Conference presentation: part of this paper was presented at the First symposium on experimental biology: sea and environment, Trapani, Italy, 24-25 May 2019.

Received for publication: 28 June 2019.

Revision received: 11 September 2019.

Accepted for publication: 12 September 2019.

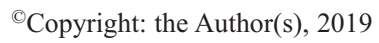

Licensee PAGEPress, Italy

Journal of Biological Research 2019; 92:8370

doi:10.4081/jbr.2019.8370

This article is distributed under the terms of the Creative Commons Attribution Noncommercial License (by-nc 4.0) which permits any noncommercial use, distribution, and reproduction in any medium, provided the original author(s) and source are credited. decrease in the number of red blood cells and an increase in the percentage of micronucleated erythrocytes through chromatin fragmentation, while abnormalities like cellular and nuclear vacuolization, collapse and rupture of the cell membrane were caused by IBU toxicity. Understanding the biological effects of these drugs on frog tadpoles can help in using these animals as reliable bio-indicator organisms in monitoring aquatic environments health.

\section{Introduction}

Nowadays, pharmaceuticals and personal care products (PPCP) that contaminate water sources are a worldwide problem. The widespread use of PPCP in hospitals, domestic residences, agricultural and industrial facilities has increased their effluent discharge into the surface waters and groundwater sediments, ${ }^{1}$ rivers, estuaries and the sea., ${ }^{2,3}$ Many studies conducted in freshwater environments ${ }^{4-6}$ and in the marine environment, ${ }^{7,8}$ have demonstrated that pharmaceuticals can cause adverse effects at concentrations typically found in the environment.

Decreases in amphibian populations have been observed on a global scale. In some cases, this phenomenon is associated with exposure to environmental pollutants such as pesticides and heavy metals. ${ }^{9-11}$ Presence of pharmaceutical components in Albanian water bodies, is a new phenomenon. One of the most frequent groups of pharmaceuticals that have been identified as being of particular concern is the nonsteroidal anti-inflammatory drugs (NSAIDs) and chemotherapeutic drugs. ${ }^{12-16}$

In contrast to other pollutants in water, drugs are molecules with high biological activity on different organisms. Even though their concentrations in surface water are detected frequently in range from $\mathrm{ng} / \mathrm{L}$ to tens of $\mu \mathrm{g} / \mathrm{L}, 5,17$ their ingrowing input into the water bodies and a long-term exposure may cause toxicity and adverse effects to aquatic organisms. ${ }^{18}$ Kolpin et al. (2002) found ibuprofen (IBU) in $10 \%$ of stream water samples with maximal concentrations of $1 \mu \mathrm{g} / \mathrm{L}$ (median $0.2 \mu \mathrm{g} / \mathrm{L}$ ). ${ }^{19}$ In two stormwater canals levels of IBU were up to $674 \mathrm{ng} / \mathrm{L}$ and of naproxen up to $145 \mathrm{ng} / \mathrm{L} .{ }^{20}$ In Norway, IBU occurred in all sewage samples, and in seawater at concentrations of $0.1-20 \mu \mathrm{g} / \mathrm{L}$ (sum of IBU and metabolites). ${ }^{21}$ In U.K. estuaries maximal concentration of 0.93 $\mu \mathrm{g} / \mathrm{L}$ (median $0.05 \mu \mathrm{g} / \mathrm{L}$ ) occurred. ${ }^{22}$ Because of their aquatic embryonic and larval development as well as their sensitivity to a wide variety of toxic agents, amphibians are suitable in studies of environmental contamination ${ }^{23,24}$ as well as for detection of genotoxic agents. ${ }^{25-27}$

Pelophylax shqipericus is a species of true frog (family 
Ranidae) and is native in Albania and Montenegro. The Albanian water frog is an endangered species and known populations are currently in decline. Environmental pollution is one of the main causes of the decrease of amphibian population worldwide. In Albania, due to uncontrolled discharge of pharmaceuticals products and agricultural activity, freshwater bodies are polluted. This mostly affects the amphibian tadpoles whose life is closely related to water. To address the problem of $P$. shqipericus population decline, an important Albanian endemic amphibian species, assisted reproductive technology has been applied successfully. ${ }^{28}$

To detect possible effects of a contaminant in the environment, standardized short-term, sensitive, and low-cost methods are applied to estimate toxicity against organisms. Since the presence of pharmaceutical components in Albanian water bodies, is a new phenomenon never reported or measured before, the aim of the present study was to elucidate the possible toxic effects of sub-lethal and environmentally relevant concentrations of IBU, a new source of contamination in the aquatic environments, and also cyclophosphamide's (CP) effects on cellular physiology of amphibian tadpoles, with aiming of using tadpoles as good and reliable bio-indicator organisms for evaluating freshwater ecosystem's health.

\section{Materials and Methods}

\section{Animals}

All sexually mature Albanian water frog P. shqipericus, were obtained from a pond near Scadar Lake $\left(42^{\circ} 10 \mathrm{~N} 19^{\circ} 19 \mathrm{E} / 42.167^{\circ} \mathrm{N}\right.$ $\left.19.317^{\circ} \mathrm{E}\right)$ in the north-western part, Albania, during the breeding season in April-May 2018. After acclimatization in the laboratory for 15 days, in vitro fertilization technique was applied, following the procedure described by Turani and Aliko (2018). ${ }^{28}$ The eggs were evaluated as successful fertilized when they reached neural stage (stage 14, according to Gosner). ${ }^{29}$ All experiments were carried out at a controlled room temperature of $20 \pm 0.58^{\circ} \mathrm{C}$. In our bioassay, P. shqipericus tadpoles at Gosner stage 21, were used.

\section{Chemicals}

IBU ( $\alpha$-methyl-4-(isobutyl) phenyl-acetic acid) is a common NSAID, prescribed for the prevention and/or treatment of several human diseases and disorders. Doses of this drug were selected based on environmental concentrations reported in the studies carried out in surface waters, lakes and seawater worldwide. CP (CAS No 50-18-0, Endoxan, Asta), a well-known mutagen, was used as a positive control at a concentration of $5 \mathrm{ppm}(\mathrm{mg} / \mathrm{L})$. All test solutions were prepared immediately before each experiment.

\section{Experimental design}

The experiment was performed by dividing $P$. shqipericus tadpoles in three groups: a negative control group $(\mathrm{n}=10)$; a positive control $(\mathrm{n}=10)$ using $5 \mathrm{mg} / \mathrm{L} \mathrm{CP}$; and an experimental group $(n=10)$ which was exposed to IBU added directly to water at a dose of $5 \mu \mathrm{g} / \mathrm{L}$ for 48 hours. During the exposure period, the tadpoles were kept in $50 \mathrm{~L}$ aquaria, with aerated water at $21^{\circ} \mathrm{C}$ and no mortality was registered. The micronuclei frequency in each group was scored after $24 \mathrm{~h}, 48 \mathrm{~h}$

\section{Blood smear preparation and analysis}

The protocol is quick and simple: tadpoles were anesthetized for approximately $2 \mathrm{~min}$ in a $5 \%$ solution of benzocaine and the blood samples were obtained by cardiac puncture, under a magnifying glass. Two peripheral blood smears for each animal were immediately prepared on clean slides, fixed in absolute methanol for $3 \mathrm{~min}$, and air dried. The slides were stained with GiemsaRomanowsky for $20 \mathrm{~min}$. For each tadpole, three slides were prepared and scored blind by a single observer, using a light microscope (Digital LCD microscope, DMC-653) linked directly with PC computer for image's processing. The micronuclei frequency was determined in 1,000 erythrocytes from each tadpole blood smear, using $1000 \times$ magnification. Coded and randomized slides were scored blind by a single observer. The frequency of micronucleated cells was expressed per 1000 cells.

\section{Statistical analysis}

Parametric analysis of variance (ANOVA) or the nonparametric analysis (Kruskal Wallis test) based on the data distribution (normality and homogeneity of variance) were used. When an indication of a significant difference $(\mathrm{P}<0.01)$ was observed, differences were analysed by the post-hoc Dunnett's test.

\section{Results and Discussion}

Red blood cells (RBCs) in lower vertebrates such as amphibians are nucleated and undergo cell division in the circulation, especially during the larval stages. These cells are therefore suitable for erythrocyte abnormalities and micronuclei detection, which can be readily counted in blood smears. ${ }^{25,30}$ The frequencies of micronuclei after treatment are shown in Table 1 and the timeresponse curves at each dose level are shown in Figure 1.

$P$. shqipericus tadpoles exposed to $5 \mu \mathrm{g} / \mathrm{L}$ IBU showed no significant increase in the frequency of micronucleated erythrocytes compared to the negative control group. Meanwhile, tadpoles exposed to $\mathrm{CP}$ (CP positive control), showed a significant increase in micronucleated erythrocytes $(\mathrm{P}<0.01)$ after 24 and 48 hours of exposure. Statistical analysis was done with ANOVA (Table 2) and Dunn's test (Table 3).

Micronuclei are formed by the loss of whole chromosomes or portions of chromosomes from daughter nuclei at mitosis and exist separately from the main nucleus of the cell. Micronuclei result

Table 1. Frequency of micronucleated red blood cells (per 1000 cells) in Pelophylax shqipericus larvae exposed to different test compounds.

\begin{tabular}{lccccc} 
Treatment & Concentration (\%) & No. of cells & No. of micronuclei & $24 \mathrm{~h}$ & 48h \\
Control & - & 10,000 & 3 & $0.33 \pm 0.04$ & $1.0 \pm 0.11$ \\
Cyclophosphamide & $5 \mathrm{mg} / \mathrm{L}$ & 10,000 & 23 & $1.04 \pm 0.12^{*}$ & $2.2 \pm 0.44^{*}$ \\
\hline Ibuprofen & $5 \mu \mathrm{g} / \mathrm{L}$ & 10,000 & 18 & $0.67 \pm 0.09$ & $0.63 \pm 0.12$ \\
\hline
\end{tabular}


either from chromosome breaks (clastogenic effects) or dysfunction of the spindle apparatus or centromere kinetochore complexes, with subsequent elimination of whole chromosomes (aneugenic effects). ${ }^{25,31}$ Compared to other cytogenetic assays, the several advantages in quantifying micronuclei include the speed and ease of analysis, and the lack of requirement for metaphase cells. ${ }^{32}$ Several authors have adapted the micronucleus test to assess the frequency of micronucleated cells in amphibians such as Pleurodeles waltl, Ambystoma mexicanum and Xenopus laevis ${ }^{33}$ and tadpoles of the anurans Rana catesbeiana and Caudiverbera caudiverbera. ${ }^{34,35}$

Due to toxicity of IBU in $P$. shqipericus tadpoles exposed for 48 hours, erythrocyte abnormalities observed were cellular and nuclear vacuolisation, collapse and rupture of the cell membrane (Figure 2). In tadpoles exposed to CP, blood smears showed a pro-

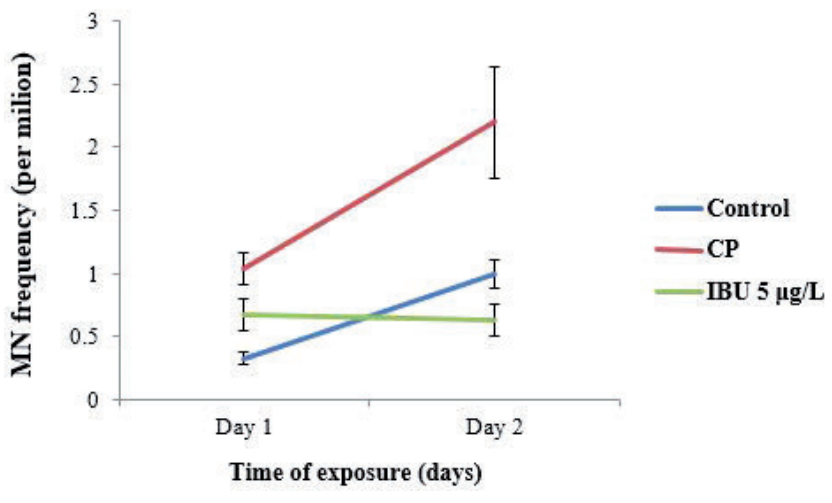

Figure 1. Variation in the micronuclei (MN) frequency with time in each treated group of Pelophylax shqipericus tadpoles. The graph shows control, cyclophosphamide (positive control) and the concentration of ibuprofen tested. Data are the mean \pm standard error. CP, cyclophosphamide; IBU, ibuprofen. nounced decrease in the number of RBCs and an increase in the percentage of the micronucleated erythrocytes through chromatin fragmentation.

Our results demonstrated that the exposure to IBU caused lesser damage in chromatin level, but elevated the percentage of erythrocyte abnormalities. There is strong evidence that the mode of action of IBU is related to non-specific inhibition of prostanoids, via inhibition of the COX enzymes. Exposure to stressors can lead
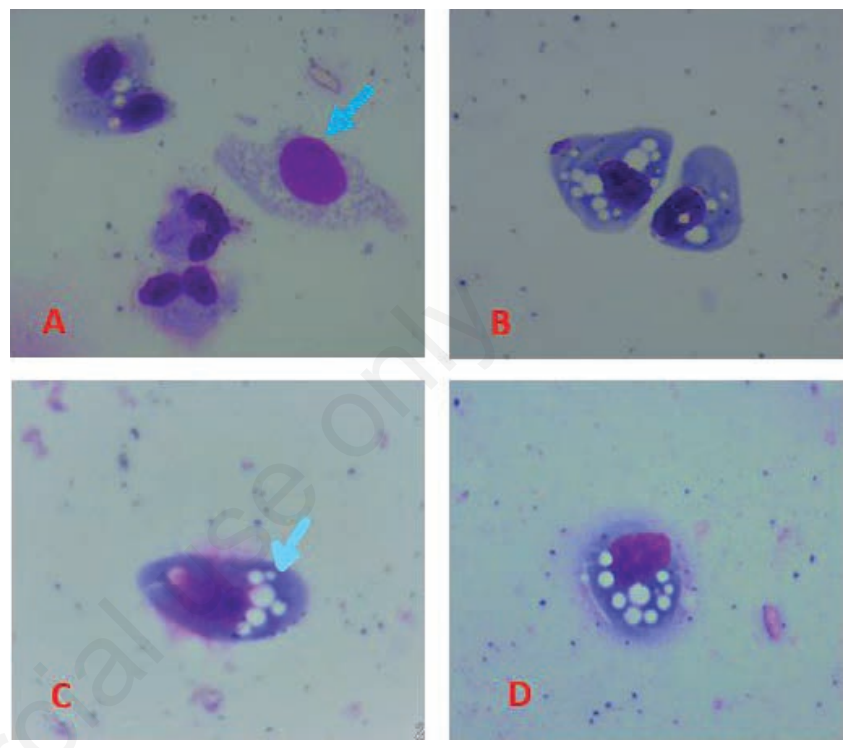

Figure 2. Erythrocyte abnormalities observed in Pelophylax shqipericus tadpole exposed to ibuprofen. Giemsa-stained blood smear 1000x. Membrane rupture (A), deformed and cytoplasmvacuolated cells $(B)$, vacuolated cell $(C)$ and erupted nucleus and cytoplasm-vacuolated cell (D).

Table 2. Statistical analysis with analysis of variance.

\begin{tabular}{lcccccc} 
Source of variation & SS & df & MS & F & P-value \\
Sample & 12.35433 & 2 & 6.177167 & 14.28736 & $1.05 \mathrm{E}-05$ & 3.168246 \\
Columns & 5.340167 & 1 & 5.340167 & 12.35144 & 0.0009 \\
\hline Interaction & 3.640333 & 2 & 1.820167 & 4.20992 & 0.019995 \\
Within & 23.347 & 54 & 0.432352 & - & - \\
\hline Total & 44.68183 & 59 & - & - & - \\
\hline
\end{tabular}

SS, Sum of Squares; df, degrees of freedom; MS, Mean Square; F, F value; F crit, $\mathrm{F}$ critical value.

Table 3. Statistical analysis with Dunnett's test.

\begin{tabular}{|c|c|c|c|c|c|c|}
\hline \multirow{3}{*}{\multicolumn{2}{|c|}{$\begin{array}{l}\text { Dunnett } t(2 \text {-sided })^{b} \\
\text { (I) Treatment }\end{array}$}} & \multicolumn{3}{|c|}{ Multiple Comparisons ${ }^{\mathrm{a}}$} & & \\
\hline & & \multirow{3}{*}{$\begin{array}{c}\text { Mean Difference } \\
\text { (I-J) } \\
1.2000^{*}\end{array}$} & \multirow{3}{*}{$\begin{array}{l}\text { Std. Evror } \\
.38893\end{array}$} & \multirow{3}{*}{$\begin{array}{l}\text { Sig. } \\
.009\end{array}$} & \multirow{2}{*}{\multicolumn{2}{|c|}{$\begin{array}{l}95 \% \text { Confidence Interval } \\
\text { Lower Bound Upper Bound }\end{array}$}} \\
\hline & & & & & & \\
\hline CP (day 1) & Control & & & & .2925 & 2.1075 \\
\hline IBU (day 1) & Control & -.3700 & .38893 & .542 & -1.2775 & .5375 \\
\hline CP (day 2) & Control & $.7100^{*}$ & .14722 & .000 & .3665 & 1.0535 \\
\hline IBU (day 2) & Control & .3400 & .14722 & .053 & -.0035 & .6835 \\
\hline
\end{tabular}

Based on observed means. The error term is Mean Square(Error)=.756. I, Treatment; J, Control; CP, cyclophosphamide; IBU, ibuprofen. ${ }^{*}$ The mean difference is significant at the .05 level. a Multiple comparisons; bunnett t-tests treat one group as a control, and compare all other groups against it. 
to pain and inflammation, which in turn increase the proliferation of prostanoids, whose implication in several homeostatic functions in nonvertebrates, such as glucose metabolism and immunity regulation, are reported. ${ }^{36}$

The most frequent erythrocyte alterations following IBU exposure, were cytoplasmic vacuoles. It has been proven that IBU acts as a $\mathrm{Ca}^{2+}$ and $\mathrm{PO}_{4}{ }^{2-}$ ions activator during the initiation of the process of opening of the channels found into the inner membrane of mitochondria. ${ }^{28}$ There is also an interaction of IBU with lysosomal membrane lipid bilayer, modifying so its morphology. This could also explain the presence of deformed erythrocytes in blood smears. In this process, the alteration of ionic channels, receptors and enzymes found embedded into the membrane lipid layer, could also have been involved. ${ }^{37,38}$

It can be speculated that endoplasmatic reticulum (ER) vacuolization can be triggered by cellular osmotic stress probably induced by IBU toxicity. In this case, ER vacuolization proceeds probably due to mitochondrial dysfunction which lead to an imbalance $\mathrm{K}^{+} / \mathrm{Na}^{+}$flux, can cause the increase of cell volume, which can lead to mitochondrial swelling. ${ }^{39}$ However, given the incomplete data about the mechanisms of vacuolization, it remains possible that, in at least some cases, vacuole accumulation is an important initiating event, causing metabolic alterations or stress responses that lead to cell death, albeit indirectly.

Decrease in red blood cells in P. shqipericus tadpoles during 24 and 48 hours of exposure to IBU suggests anemic condition in the exposed animals. This may be happened due to the deleterious effect of IBU on the hematopoietic system, by inhibiting erythropoiesis via transferrin dysfunction. ${ }^{40}$

Our findings demonstrate the exposure to IBU causes several haematological damages, especially erythrocyte-related. It is very likely that IBU causes oxidative stress followed by eryptosis and animal health impairment. Thus, amphibian embryos represent a very useful bio-indicator model organism of in vivo studies of different pharmaceuticals effect on freshwater biota.

\section{Conclusions}

Tadpoles of $P$. shqipericus can be very good bio-indicators for in vivo monitoring of IBU pollution in aquatic environments. This study adds amphibian embryos as an alternative model to study the toxicity of pharmaceuticals.

\section{References}

1. Zuccato E, Calamari D, Natangelo M, Fanelli R. Presence of therapeutic drugs in the environment. Lancet 2000;355:1789-90.

2. Carlsson C, Johansson AK, Alvan G, et al. Are pharmaceuticals potent environmental pollutants? Part I: environmental risk assessment of selected active pharmaceutical ingredients. Sci Total Environ 2006;364:67-87.

3. Bendz D, Paxeus NA, Ginn TR, Loge FJ. Occurrence and fate of pharmaceutically active compounds in the environment, a case study: Hoje River in Sweden. J Hazard Mater 2005;122: 125-204.

4. Brain RA, Johnson DJ, Richard SM, et al. Microcosm evaluation of the effects of an eight pharmaceutical mixture to the aquatic macrophytes Lemna gibba and Myriophyllum sibiricum. Aquat Toxicol 2004;70:23-40.
5. Fent K, Weston A, Caminada D. Ecotoxicology of human pharmaceuticals. Aquat Toxicol 2006;76:122-59.

6. Isidori M, Nardelli A, Parrella A, et al. A multispecies study to assess the toxic and genotoxic effect of pharmaceuticals: furosemide and its photoproduct. Chemosphere 2006;63:785-93.

7. Martin-Diaz ML, Gagne F, Blaise C. The use of biochemical responses to assess eco toxicological effects of pharmaceuticals and personal care products (PPCPs) after injection in the mussel, Elliptio complanata. Environ Toxicol Phar 2009;28:237-42.

8. Owuor M, Salamanca MJ, Martin-Diaz ML, Dell Walls TA. Acute toxicity determination of four selected pharmaceuticals using the bacteria Vibrio fischeri (MirotoxR) and the sea urchin Paracentrotus lividua (Echinodermata: Echinoidea) (Lamark, 1816) fertilization/embryo-larval bioassays. Master thesis, University of Cadiz, Spain; 2009.

9. Turani B, Aliko V. Sensitivity of early life stages of Pelophylax shqipericus to xenobiotics. Proceedings of the 3rd International Conference on Challenges in Biotechnological and Environmental Approaches, 2019 Apr 23-24, Tirana, Albania. Albanian J Agric Sci 2019;18:119-27.

10. Collins JP, Storfer A. Global amphibian declines: sorting the hypotheses. Divers Distrib 2003;9:89-98.

11. Davidson C, Shaffer HB, Jennings MR. Declines of the California red-legged frog: climate, UV-B, habitat and pesticides hypothesis. Ecol Appl 2001;11:464-79.

12. Veldhoen N, Skirrow RC, Brown LLY, et al. Effects of acute exposure to the non-steroidal anti-inflammatory drug ibuprofen on the developing North America bullfrog (Rana catesbeiana) tadpole. Environ Sci Technol 2014;48:10439-47.

13. Triebskorn R, Casper H, Heyd A, et al. Toxic effects of the non-steroidal anti-inflammatory drug diclofenac. Aquat Toxicol 2004;68:151-66.

14. Gómez-Oliván LM, Galar-Martínez M, García-Medina S, et al. Genotoxic response and oxidative stress induced by diclofenac, ibuprofen and naproxen in Daphnia magna. Drug Chem Toxicol 2014;37:391-9.

15. Vishma BL, Sujayraj RS, Prashantha N. Attenuation of cyclophosphamide-induced genotoxicity and oxidative stress by Justicia wynaadensis (Nees) T. Anders - A study in Swiss Albino Mice. IJSR 2017;6:54-7.

16. Pereira da Costa Araújo AA, Mesak C, Montalvão MF, et al. Anti-cancer drugs in aquatic environment can cause cancer: Insight about mutagenicity in tadpoles. Sci Total Environ 2019;650:2284-93.

17. Gomez MJ, Martinez-Bueno M, Lacorte S, et al. Pilot survey monitoring pharmaceuticals and related compounds in a sewage treatment plant located on the Mediterranean Coast. Chemosphere 2007;66:993-1002.

18. Pomati F, Castiglioni S, Zuccato E, et al. Effects of complex mixture of therapeutic drugs at environmental levels on human embryonic cells. Environ Sci Technol 2006;40:2442-7.

19. Kolpin DW, Furlong ET, Meyer MT, et al. Pharmaceuticals, hormones, and other organic wastewater contaminants in U.S. streams 1999-2000: a national reconnaissance. Environ Sci Technol 2002;36:1202-11.

20. Boyd GR, Palmeri JM, Zhang S, Grimm DA. Pharmaceuticals and personal care products (PPCPs) and endocrine disrupting chemicals (EDCs) in storm water canals and Bayou St. John in New Orleans, Louisiana, USA. Sci Total Environ 2004;333:137-48.

21. Weigel S, Berger U, Jensen E, et al. Determination of selected pharmaceuticals and caffeine in sewage and seawater from Tromso/Norway with emphasis on ibuprofen and its metabolites. Chemosphere 2004;56:583-92. 
22. Thomas KV, Hilton MJ. The occurrence of selected human pharmaceutical compounds in UK estuaries. Mar Pollut Bull 2004;49:436-44.

23. Bustuoabad O, Herkovits J, Pisanó A. Different sensitivity to lithium ion during the segmentation of Bufo arenarum eggs. Acta Embryol Exp 1977;3:271-82.

24. Cooke AS. Tadpoles as indicators of harmful levels of pollution in the field. Environ Pollut 1981;25:123-33.

25. Campana MA, Panzeri AM, Moreno VJ, Dulout FN. Micronuclei induction in Rana catesbeiana tadpoles by the pyrethroid insecticide lambda-cyhalothrin. Genet Mol Biol 2003;26:99-104.

26. Ossana NA, Castañé PM, Poletta GL, et al. Toxicity of waterborne copper in premetamorphic tadpoles of Lithobates catesbeianus (Shaw, 1802). Bull Environ Contam Toxicol 2010;84:712-5.

27. Bouhafs N, Berrebbah H, Devaux A, et al. Micronucleus induction in erythrocytes of tadpole Rana saharica (Green Frog of North Africa) exposed to Artea 330EC. Am-Euras J Toxicol Sci 2009; 1:7-12.

28. Turani B, Aliko V. Development of assisted reproduction technologies for the endangered Albanian water frog (Pelophylax shqipericus): from gamete release to froglets. International Agricultural, Biological \& Life Science Conference 2018. Proceedings of the International Agricultural, Biological \& Life Science Conference, 2018 Sep 2-5, Edirne, Turkey. pp 152-160.

29. Gosner KL. A simplified table for staging anuran embryos and larvae with notes on identification. Herpetologica 1960;16:183-90.

30. Machado Da Rocha CA. The micronucleus test in erythrocytes of amphibian larvae as tool for xenobiotic exposure risk assessment: a brief review and an example using Lithobates Catesbeianus exposed to copper sulphate. Middle-East J Sci Res 2011;8:23-9.
31. Fenech $\mathrm{M}$. The in vitro micronucleus technique. Mutat Res 2000;455:81-95.

32. Gauthier L, Van der Gaag MA, Haridon LJ, et al. In vivo detection of waste water and industrial effluent genotoxicity: use of the newt micronucleus test (Jaylet test). Sci Total Environ 1993;138:249-69.

33. Fernández M, Haridon JL, Gauthier L, Zoll-Moreux C. Amphibian micronucleus test(s): a simple and reliable method for evaluating in vivo genotoxic effects of freshwater pollutants and radiations. Initial assessment. Mutat Res 1993;292:83-99.

34. Krauter PW, Anderson SL, Harrison FL. Radiation-induced micronuclei in peripheral erythrocytes of Rana catesbeiana: an aquatic animal model for in vivo genotoxicity studies. Environ Mol Mutagen 1987;10:285-96.

35. Venegas W, Hermosilla I, Gavilan JF, et al. Larval stages of the anuran amphibian Caudiverbera caudiverbera: a biological model for studies for genotoxic agents. Bol Soc Biol Concept 1987;58:171-9.

36. Gómez-Abellán V, Sepulcre MP. The role of prostaglandins in the regulation of fish immunity. Mol Immunol 2016; 69:139-45.

37. Al-Naseer IA. Ibuprofen-induced liver mitochondrial permeability transition. Toxicol Lett 2000;111:213-8.

38. Manrique-Moreno M, Villena F, Sotomayor CP, et al. Human cells and cell membrane molecular models are affected in vitro by the nonsteroidal anti-inflammatory drug ibuprofen. Biochem Biophys Acta 2011;1808:2656-64.

39. Shubin AV, Demidyuk IV, Komissarov AA, et al. Cytoplasmic vacuolization in cell death and survival. Oncotarget 2016;7:55863-89.

40. Javed M, Ahmad I, Ahmad A, et al. Studies on the alterations in haematological indices, micronuclei induction and pathological marker enzyme activities in Channa punctatus (spotted snakehead) Perciformes, Channidae exposed to thermal power plant effluent. Springerplus 2016;5:761. 